\title{
PROFIL KONDILOMA AKUMINATA DI POLIKLINIK KULIT DAN KELAMIN RSUP PROF.DR. R.D. KANDOU MANADO PERIODE JANUARI 2012 - DESEMBER 2012
}

\author{
${ }^{1}$ Stella R. Nelwan \\ ${ }^{2}$ Nurdjannah J. Niode \\ ${ }^{2}$ Marlyn G. Kapantow \\ ${ }^{1}$ Kandidat skripsi Fakultas Kedokteran Universitas Sam Ratulangi Manado \\ ${ }^{2}$ Bagian/SMF Kulit dan Kelamin RSUP Prof. Dr.R.D.Kandou Manado \\ Email: Stellanelwan@gmail.com
}

\begin{abstract}
Condyloma acuminata, also known as genital warts, is a vegetation of certain types of Human Papilloma Virus(HPV), stalky with bumpy surface. This disease is a sexually transmitted disease, most HPV infections in anogenital area are acquired during sex. This was a descriptive retrospective study, where the data were collected from medical records and registers book of sexually transmitted disease (STD) in Dermatovenereology clinic of Prof. Dr. R. D. Kandou Hospital Manado. The result showed that in 2012, there were 27 new cases of condyloma acuminata, 2.46\% of all new patients Most age group found was 25-44 years which was 13 patients (48.15\%), with sex distribution mostly found in female patients which was 14 patients (51.85\%). Most occupation found was private employees by 10 patients (37.04\%). Most affected locations in female patients was vulva and vulva with vagina by 5 patients each of them (35.71\%), where as in male patients was penis which was found in 4 patients. The result also showed that HIV was the most comorbid disease found in 3 patients (11.11\%). Conclusion: In this study, most condyloma acuminata patients is in 25-44 age group, mostly found in female, most occupation was private employee, most location affected in female were vulva and vulva with vagina, while in male patients was penis, most therapy used was podophyllin. Most comorbid disease was HIV.
\end{abstract}

Keywords: Condyloma acuminata, Human papilloma virus, female

Abstrak: Kondiloma akuminata (KA) adalah vegetasi oleh Human Papilloma Virus (HPV) tipe tertentu, bertangkai dengan permukaannya berjonjot. Penyakit ini tergolong infeksi menular seksual, kebanyakan infeksi HPV di daerah anogenital didapatkan melalui hubungan seksual. Penelitian ini bersifat deskriptif retrospektif; data diambil dari rekam medik dan buku register infeksi menular seksual bagian ilmu penyakit kulit dan kelamin RSU Prof. Dr. R. D. Kandou Manado. Hasil penelitian memperlihatkan pada tahun 2012 dari total kunjungan baru terdapat 27 kasus baru KA (2,46\%). Kelompok umur terbanyak didapatkan adalah 25-44 tahun sebanyak 13 orang $(48,15 \%)$ dengan jenis kelamin terbanyak perempuan sebanyak 14 orang $(51,85 \%)$ Pada pekerjaan terbanyak pada pekerja swasta sebanyak 10 orang (37,04\%) Lokasi lesi pada perempuan tersering di vulva dan vulva ditambah vagina masing-masing sebanyak 5 orang $(35,71 \%)$, sedangkan pada laki-laki tersering di penis yaitu sebanyak 4 orang. Hasil penelitian juga didapatkan penyakit penyerta terbanyak adalah HIV sebanyak 3 orang $(11,11 \%)$. Simpulan: Dalam Penelitian ini, pasien KA terbanyak pada kelompok umur 25-44 tahun paling banyak pada perempuan, jenis pekerjaan pegawai, lokasi lesi pada perempuan tersering pada vulva dan vulva ditambah vagina sedangkan pada laki-laki tersering di penis, pengobatan tersering podofilin. Penyakit penyerta ada lah HIV.

Kata kunci:Kondiloma Akuminta, Human papilloma virus, Perempuan. 
Kondiloma Akuminata (KA) adalah vegetasi oleh Human Papilloma Virus (HPV) tipe tertentu, bertangkai dangan permukaannya berjonjot. ${ }^{1}$ Di Amerika serikat, data dari Center for Disease Control and Prevention tercatatada lebih dari 19,7 juta kasus baru infeksi menular seksual (IMS) tiap tahun, dan 14,1 juta kasus merupakan infeksi HPV. ${ }^{2}$ Di Indonesia, penelitian IMS di 12 Rumah Sakit Pendidikan tahun 2007-2011, termasukManado, KA menduduki peringkat ke 3 terbesar. KA menduduki peringkat pertama di 6 kota yaitu di Medan, Jakarta, Bandung, Semarang, Jogja dan Denpasar. Usia terbanyak didapatkan pada golongan usia 25-45 tahun. ${ }^{3} \mathrm{Di}$ RSUP. H. Adam Malik, Medan tahun 2009 didapatkan IMS yang paling sering adalah KA yaitu sebanyak 29,9\%. ${ }^{4}$ Sedangkan di RSUD Dr. Soetomo Surabaya, angka kesakitan KA tahun 2006 adalah 1,7\% danpadatahun 2008 meningkat menjadi $1,9 \%$, terbanyak pada perempuan(3:2) dan pada umur 25-44 tahun. ${ }^{5}$

HPV tipe low risk atau tipe berisiko rendah berhubungan dengan KA seperti tipe 6 dan $11 .{ }^{6}$ Kebanyakan infeksi HPV di daerah anogenital didapatkan melalui hubungan seksual. HPV masuk kedalam tubuh melalui mikrolesi pada kulit. Masa inkubasi KA berlangsung antara 1-8 bulan (rata-rata 2-3 bulan). ${ }^{6}$

Penyakit ini terutama terdapat di daerah lipatan yang lembab, misalnya di daerah genitalia eksterna. Pada pria predileksinya di perineum dan sekitar anus, sulkus koronarius, glans penis, muara uretra eksterna, korpus, dan pangkal penis. Pada wanita di daerah vulva dan sekitarnya, introitus vagina, kadangkadang pada porsio uteri. ${ }^{1}$
Pengobatan KA antara lain adalah Podofilin,yang digunakan tingtur podofilin 25\%. Pengobatan ini tidak boleh diberikan pada wanita hamil.Selain itu ada Asam trikloro asetat (TCA) yang digunakan larutan dengan konsentrasi 50\%, lalu ada 5-Fluorourasi, interferon, imunoterapi, dan tindakan bedah bisa dengan cara listrik, beku, skalpel atau laser. ${ }^{1,6,7}$

Tujuan penelitian ini untuk mengetahui profil pasien KA di Poliklinik Kulit dan Kelamin RSUP. Prof. Dr. R. D. Kandou Manado Periode Januari 2012Desember 2012.

\section{METODE PENELITIAN}

Penelitian ini bersifat deskriptif retrospektif. Data diambil dari rekam medik dan buku register infeksi menular seksual di Poliklinik kulit dan kelamin RSUP Prof. Dr. R.D. Kandou Manado.

Populasi mencakup seluruh data pasien yang datang berobat di poliklinik kulit dan kelamin pada tahun 2012. Semua pasien baru yang didiagnosa dengan KA yang berobat di Poliklinik di Poliklinik Kulit dan Kelamin Prof. Dr. R.D Kandou Manado periodeJanuari 2012- Desember 2012. Variabel penelitian meliputi umur, jenis kelamin, pekerjaan, lokasi lesi, pengobatan, dan penyakit penyerta.

\section{HASIL PENELITIAN}

Dari hasil penelitian Deskriptif Retrospektif yang telah di lakukan di Bagian Poliklinik Kulit Kelamin dan Pusat Rekam Medik RSUP Prof.Dr.R.D Kandou Manado didapatkan ada 27 pasien baru KA dengan persentasi sebanyak 2,46 dari 1.096 kunjungan baru pada periode Januari 2012 - Desember 2012. 
Tabel 1. Distribusi pasien baru KA menurut umur.

\begin{tabular}{lcc}
\hline Umur & jumlah & Persentasi (\%) \\
\hline$<1$ & 0 & 0,00 \\
$1-4$ & 0 & 0,00 \\
$5-14$ & 0 & 0,00 \\
$15-24$ & 8 & 29,63 \\
$25-44$ & 13 & 48,15 \\
$45-64$ & 6 & 22,22 \\
$\geq 65$ & 0 & 0,00 \\
\hline Total & 27 & 100 \\
\hline
\end{tabular}

Tabel 2. Distribusi pasien baru KA menurut jenis kelamin.

\begin{tabular}{lcc}
\hline Jenis kelamin & Jumlah & Persentasi (\%) \\
\hline Laki-laki & 13 & 48,15 \\
Perempuan & 14 & 51,85 \\
\hline Total & 27 & 100 \\
\hline
\end{tabular}

Tabel 3. Distribusi pasien baru KA berdasarkan pekerjaan.

\begin{tabular}{lcc}
\hline Pekerjaan & Jumlah & Persentasi (\%) \\
\hline Tidak ada & 5 & 18,52 \\
Ibu Rumah Tangga & 5 & 18,52 \\
Pelajar & 2 & 7,41 \\
PNS & 3 & 11,11 \\
Swasta & 10 & 37,04 \\
Petani & 2 & 7,41 \\
\hline Total & 27 & 100 \\
\hline
\end{tabular}

Distribusi pasien KA menurut umur, didapatkan terbanyak pada kelompok umur 25 - 44 tahun yaitu sebanyak 13 orang $(48,15 \%)$ (Tabel $1)$.

Distribusi pasien KA menurut jenis kelamin terbanyak pada perempuan sebanyak 14 orang (51,85\%) (Tabel 2).

Distribusi pasien KA menurut pekerjaan di dapatkan bahwa pasienKA paling banyak ditemukan pada pekerja swasta yaitu 10 orang (37,04\%) (Tabel 3).
Distribusi pasien KA menurut lokasi lesi, didapatkan pada perempuan yang paling sering yaitu di vulva sebanyak 5 orang (35,71\%), begitu juga vulva + vagina yaitu sebanyak 5 orang $(35,71 \%)$ (Tabel 4). Sedangkan pada laki-laki tersering pada penis yaitu sebanyak 4 orang (30,77\%) (Tabel 5).

Distribusi pasien menurut terapi yang diberikan, didapatkan paling sering di gunakan pada pasien KA adalah Podofilin yaitu sebanyak 14 orang (51,85\%) (Tabel 6). 
Tabel 4. Distribusi pasien baru KA berdasarkan lokasi lesi pada Perempuan.

\begin{tabular}{lcc}
\hline Lokasi lesi & Jumlah & Persentasi (\%) \\
\hline Vulva & 5 & 35,71 \\
Perianal & 2 & 14,29 \\
Vulva+vagina & 5 & 35,71 \\
Vulva + Perianal & 1 & 7,14 \\
Vagina+cervix & 1 & 7,14 \\
\hline Total & 14 & 100 \\
\hline
\end{tabular}

Tabel 5. Distribusi pasien baru KA berdasarkan lokasi lesi pada Laki - laki.

\begin{tabular}{lcc}
\hline Lokasi lesi & jumlah & Persentasi(\%) \\
\hline Glands penis & 2 & 15,38 \\
Penis & 4 & 30,77 \\
Preputium & 2 & 15,38 \\
Pubis & 1 & 7,69 \\
Skrotalis & 1 & 7,69 \\
Preputium + glands penis & 2 & 15,38 \\
Glands penis + corpus penis & 1 & 7,69 \\
\hline total & 13 & 100 \\
\hline
\end{tabular}

Tabel 6. Distribusi pasien baru KA berdasarkan terapi

\begin{tabular}{lcc}
\hline Terapi & Jumlah & Persentasi (\%) \\
\hline Podofilin & 14 & 51,85 \\
Asam trikloro asetat (TCA) & 8 & 29,63 \\
Kauterisasi & 2 & 7,41 \\
TCA+podofilin+kauterisasi & 3 & 11,11 \\
\hline Total & 27 & 100 \\
\hline
\end{tabular}

Tabel 7. Distribusi pasien baru KA berdasarkan penyakit penyerta

\begin{tabular}{lcc}
\hline penyakit penyerta & jumlah & Persentasi (\%) \\
\hline Kandidosis vulvavaginal (KVV) & 2 & 7.41 \\
Bakterial vaginosis (BV) & 2 & 7.41 \\
Uretritis gonokokus & 1 & 3.70 \\
Human Immunodeficiency Virus & 3 & 11.11 \\
Tinea Corporis & 1 & 3.70 \\
KVV+BV & 1 & 3.70 \\
Tidak ada & 17 & 62.96 \\
\hline Total & 27 & 100 \\
\hline
\end{tabular}

Distribusi pasien menurutPenyakit penyerta yang didapatkan paling banyak yaitu Human

\section{BAHASAN}

Immunodeficiency Virus(HIV)

Pada Januari $2012 \quad-$

sebanyak 3 orang (11,11\%) (Tabel

Desember 2012 di RSUP Prof. Dr. R.

7)

D. Kandou Manado, ditemukan

pasienKA sebanyak 27 orang 
(2,46\%) dari 1096 orang dalam kurun waktu tersebut.

Pada tabel 1 kelompok umur yang terbanyak adalah pada kelompok umur 25 - 44 tahun yaitu sebanyak 13 orang (48,15\%). Hasil ini sama dengan yang dilakukan sebelumnya di 12 Rumah Sakit Pendidikan yaitu kelompok umur adalah umur 25-45 tahun. ${ }^{3}$ Begitu juga penelitian di RSUD Dr. Soetomo Surabaya tahun 2006 2008 kelompok umur yang terbanyak adalah 25-44 tahun. ${ }^{5}$ Hal ini sesuai dengan teori yang menyatakan bahwainfeksi KA terbesar terjadi pada masa seksual aktif dan ada kemungkinan kecendurungan perubahan kebiasaan pola hidup seksual dan sikap berganti atau menambah pasangan pada kelompok umur ini bisa berperan dalam kenaikan prevalensi infeksi HPV khusnya KA . 5,8

Pada tabel 2 jenis kelamin terbanyak adalah pasien perempuan yaitu14 orang (51,85\%).Hasil ini sama dengan data dari penelitian sebelumnya di RSUD Dr. Soetomo Surabaya tahun $2006-2008$. Pasienperempuan yang lebih banyak dimungkinkan karena keadaan genitalia perempuan yang mudah terjadi lesi yaitu mukosa yang lebih tipis,lebih lembab, luas, vaskularisasi banyak, sehingga rentan terinfeksi. ${ }^{2,5,6}$

Pada tabel 3 pekerjaan yang paling sering ditemukan adalah swasta sebanyak 10 orang $(37,04 \%)$. Banyaknya pasien KA dari pekerja swasta mungkin disebabkan karena mereka mempunyai banyak waktu luang, penghasilan yang cukup, serta pergaulan yang luas baik di dalam lingkungan pekerjaan maupun di luar pekerjaan. Sebuah penelitian mengatakan bahwa pelanggan dari pekerja seks komersial terbanyak dari pekerja swasta, ini mungkin dapat dihubungkan dengan tingginya resiko IMS dan KA pada kalangan ini. $^{9}$

Pada tabel 4 lokasi lesi yang paling sering ditemukan pada Perempuan yaitu pada vulva dan vulva ditambahvagina masingmasing sebanyak 5 orang (35,71\%). Hal ini sesuai dengan kepustakaan yang mengatakan bahwa KA terutama terdapat di daerah lipatan yang lembab pada genitalia eksterna. Pada tabel 5 lokasi lesi, yang paling sering ditemukan pada Laki lakiterbanyak pada penis sebanyak 4 orang (30,77\%). Lokasi-lokasi tersebut mungkin merupakan daerah yang mudah mengalami trauma saat hubungan seksual sehingga terjadi mikro lesi yang menjadi tempat masuknya infeksi virus. ${ }^{1,6}$

Pada tabel 6 terapi yang paling sering digunakan yaitu Podofilinsebanyak 14 orang $(51,85)$. Podofilin menjadi pengobatan KA yang paling sering bisa karena podofilin merupakan pengobatan yang paling banyak diketahui serta banyak tersedia secara luas, podofilin juga menjadi rekomendasi pertama untuk pengobatan KA. Keuntungan podofilin ialah mudah digunakan dan tidak mahal namun podofilin tidak dapat diberikan pada wanita hamil. ${ }^{10}$ 
Dalam penelitian ini beberapa pasien mendapatkan lebih dari satu modalitas terapi, jika modalitas pertama tidak berhasil diberikan modalitas kedua.

Pada tabel 7, didapatkan paling banyak yaitu dan Human Immunodeficiency Virus(HIV) sebanyak 3 orang(11,11\%),kedua penyakit ini saling berhubungan antara lain KA merupakan faktor resiko dari HIV. Pada pasien HIV, KA atau IMS lain yang sudah diderita dapat menjadi lebih berat, berulang atau dapat resisten karna terjadi ketidakmampuan sistem imunitas pasien untuk melawan masuknya kuman patogen. ${ }^{11,12}$

\section{SIMPULAN}

Dalam periode januari 2012 desember 2012 didapatkan pasien KA terbanyak pada kelompok umur 25 - 45 tahun, terbanyak pada perempuan, pekerjaan swasta, lokasi lesi di vulva dan vulva ditambah vagina untuk perempuan dan di penis untuk laki-laki. Terbanyak sebagai Pengobatan yaitu Podofilin dan penyakit penyerta adalah HIV.

\section{UCAPAN TERIMA KASIH}

Terima kasih pada dr. Nurdjannah J. Niode, SpKK sebagai dosen pembimbing I dan dr. Marlyn G. Kapantow, sebagai dosen pembimbing II, juga pada Prof. Dr. Hery Pandeleke, M.Sc SpKK (K) sebagai dosen penguji I dan dr. Renate T. Kandou, SPKK sebagai Dosen Penguji II, serta kepada semua pihak yang secara langsung dan tidak langsung telah memberikan gagasan pada artikel ini.

\section{DAFTAR PUSTAKA}

1. Zubier F. Kondilomata Akuminata.dalam Daili SF, Makes WIB, Zubier F, (editor).Penyakit Menular Seksual.Edisi 4Jakarta: Balai Penerbit FKUI; 2011.h. 140-5

2. Centers for Disease Control and Prevention: Incidence, Prevalence, and Cost of Sexually Transmitted Infections in the United

State.2013.

[diakses 15 September 2013]; diunduh dari http://www.cdc.gov/std/stats/STIEstimates-Fact-Sheet-Feb2013.pdf

3. Indriatmi W. Epidemiologi Infeksi Menular Seksual. 2012.dibawakan pada Simposium Sexually Transmitted Infections A rising concern 15-16 September 2012 Semarang

4. Silitonga, tetraulina J. Gambaran Infeksi Menular Seksual di RSUP. H. Adam Malik Tahun 2009.

2011 [diakses 15 September 2013]; diunduh dari http://repository.usu.ac.id/bitstrea $\underline{\text { m/123456789/26065/7/Cover.pdf }}$

5. Lumintang $\mathrm{H}$, Murtiastutik $\mathrm{D}$. The Profile of New Patient Condyloma Accuminata at Departement

Dermatovenereology Dr. Soetomo Hospital Surabaya in 2008-2009.

2011

[diakses 15 September 2013]; diunduh dari journal.unair.ac.id 
6. Handoko, RP. Penyakit Virus. dalam Djuanda A, Hamzah M, Aisah S(editor).Ilmu Penyakit Kulit dan Kelamin. Edisi 5.Jakarta: Balai Penerbit FKUI:2010.h. 113-14

7. International Union Againts Sexually Transmitted Infections Europe. Genital Warts - Patient Information leaflet.2012 [diakses 15 September 2013] diunduh dari www.iusti.org/regions/europe/pdf /2012/PIL\%20Genital520warts.p df

8. Gewirtzman A, Bobrick L, Conner K, Tyring SK. Epidemiology of Sexually Transmitted Infections.2011

9. Aprillianingrum F. Faktor Resiko Kondiloma Akuminata Pada Pekerja Seks Komersial. [Tesis]. [Semarang]. Universitas Dipenogoro: 2006 . [diakses 2 Januari 2014] diunduh dari :http://eprints.undip.ac.id/15543/ 1/Farida_Aprillianingrum.pdf

10. Chang GJ, Mark LW. Human Papilloma Virus, Condyloma Acuminata, Anal neoplasma. Clinics in Colon in Rectal Surgery.2004;17.h.221-30

11. I Ketut S, Santoso IM, Wiraguna AAGP. Giant Kondiloma Akuminata Pada Seorang Wanita Hamil dengan Vaginosis Bakterial, Kandidiasis Vulvovaginalis dan HIV stadium II. Makalah Pertemuan Ilmiah Tahun X 29 - 31 Oktober; Anyer. 2009

12. Niode NJ, Oroh EE, Waraouw WF, Daili SF, Nugroho A, Ramli D, dkk. Kondiloma Akuminata Raksasa Pada Pasien AIDS. Media Dermato-Venereologica Indonesiana.2012;39.h.165-68 